\title{
The Application and Interpretation by South African \\ Courts of General Renvoi Clauses in South African \\ Double Taxation Agreements
}

E Jansen van Rensburg*

\section{P.E.R}

Pioneer in peer-reviewed, open access online law publications

Author

Enelia Jansen van Rensburg

Affiliation

University of Stellenbosch

South Africa

Email enelia@sun.ac.za

Date Submission

6 February 2018

Date Revised

19 September 2019

Date Accepted

19 September 2019

Date published

20 November 2019

\section{Editor Prof C Rautenbach}

How to cite this article

Jansen van Rensburg E "The Application and Interpretation by South African Courts of General Renvoi Clauses in South African Double Taxation Agreements" PER / PELJ 2019(22) - DOI

http://dx.doi.org/10.17159/17273781/2019/v22i0a4402

\section{Copyright}

\section{DOI}

http://dx.doi.org/10.17159/1727-

3781/2019/v22i0a4402

\section{Abstract}

General renvoi clauses in DTAs based on article 3(2) of the OECD MTC provide that an undefined term in a DTA shall have the meaning that it has in the domestic law of the contracting state applying the DTA unless the context otherwise requires. All South African DTAs include such a clause.

Many interpretational issues remain with regard to the application and interpretation of general renvoi clauses. This article considers four of these issues in the light of South African cases in which general renvoi clauses were referred to. The following cases are considered: ITC 789 (1954) 19 SATC 434, Baldwins (South Africa) Ltd v Commissioner for Inland Revenue (1961) 24 SATC 270 and Commissioner for the South African Revenue Service $v$ Tradehold Ltd 20123 All SA 15 (SCA).

The first of the issues considered in the article is relevant in those cases where a DTA includes a general renvoi clause based on the pre-1995 version of article 3(2) and where amendments were made to a relevant domestic meaning after the conclusion of the particular DTA. These clauses do not expressly state whether the relevant domestic meaning is the domestic meaning existing at the time of the conclusion of the DTA, or at the time of the application of the DTA.

The second issue arises if the expression used in the domestic law is not identical to the undefined treaty term. The question is whether the expression in the domestic law can be used to give meaning to the treaty term under the general renvoi clause.

Another interpretational issue considered in the article concerns deeming provisions in the domestic law. The issue is whether a meaning that a term is deemed to have under a provision in domestic legislation can be used under the general renvoi clause to give meaning to the undefined term in the DTA.

The last issue deals with the meaning of the phrase "unless the context otherwise requires". The question raised is whether this phrase means that the domestic meaning should be given only as a "last resort", or whether it should apply unless "reasonably strong" arguments to the contrary are made.

\section{Keywords}

Article 3(2); general renvoi clauses; ITC 789; Baldwins; Tradehold. 


\section{Introduction}

South African double taxation agreements (DTAs) generally adhere in many respects to the Model Tax Convention on Income and on Capital of the Organisation for Economic Co-operation and Development (OECD MTC). ${ }^{1}$ The OECD MTC defines only a few of the terms used therein and, in respect of the interpretation of undefined terms, includes the general renvoi clause, article 3(2). All South African DTAs also include a version of this clause. ${ }^{2}$

\section{Article 3(2) currently reads as follows: ${ }^{3}$}

As regards the application of the Convention at any time by a Contracting State, any term not defined therein shall, unless the context otherwise requires or the competent authorities agree to a different meaning pursuant to the provisions of Article 25, have the meaning that it has at that time under the law of that State for the purposes of the taxes to which the Convention applies, any meaning under the applicable tax laws of that State prevailing over a meaning given to the term under other laws of that State.

The inclusion of a provision in a treaty that deals with the interpretation of undefined terms is somewhat unusual, ${ }^{4}$ but there are a number of reasons for including such a provision in treaties aiming to grant relief against international juridical double taxation. ${ }^{5}$ There is, namely, a need for DTAs to closely interact with the contracting states' domestic tax laws, since DTAs place a restriction on the contracting states' right to levy taxes under these domestic tax laws. ${ }^{6}$ If the domestic laws change, which they frequently do,

Enelia Jansen van Rensburg. BA Law LLB (US) LLM Taxation (UCT) LLD (UP). Senior Lecturer, University of Stellenbosch, South Africa. E-mail: enelia@sun.ac.za. This article emanated from research that the author conducted relating to her LLD dissertation at the University of Pretoria. The financial assistance of the National Research Foundation (NRF) towards this research is hereby acknowledged. The opinions expressed and conclusions arrived at are those of the author and are not to be attributed to the NRF.

1 Hattingh "South Africa" 238-239. He also points out that South African DTAs typically deviate from the OECD MTC with regard to those provisions in respect of which South Africa has noted a position on the OECD MTC. South Africa, as a non-member of the OECD, is allowed to note its position on the articles of the OECD MTC and the Commentaries to the OECD MTC. South Africa has not noted a position with regard to art 3(2) of the OECD MTC or the Commentary pertaining to that article.

$2 \quad$ Article 3(2) of the OECD MTC has been amended a number of times over the years. The wording of a general renvoi clause included in a particular DTA is usually based on the version of art 3(2) that was included in the OECD MTC during the time that the DTA was negotiated. Baker Double Taxation Conventions para E.20 mentions some of the terms commonly used to refer to these clauses.

3 The OECD MTC as at 21 November 2017.

$4 \quad$ Avery Jones et al 1984 BTR (I) 16; Baker Double Taxation Conventions para E.19.

$5 \quad$ The title and preamble to the OECD MTC (2017) include the granting of relief against international double taxation as one of the objects of a DTA. Also see Gutuza 2016 SA Merc LJ 491.

$6 \quad$ Avery Jones et al 1984 BTR (I) 17; De Broe International Tax Planning and Prevention of Abuse 263; Kandev 2007 Can Tax J 38; Rust "Article 3(2) OECD and 
there also is a need for DTAs to adapt to these changes without requiring in each instance a renegotiation of the treaty. ${ }^{7}$

The application and interpretation of general renvoi clauses raise numerous questions, many of which have been addressed by tax scholars and foreign courts. From a South African perspective, four of these issues in particular have been addressed in judgments by South African courts, and the aim of this article is to consider how the South African courts have dealt with these issues. ${ }^{8}$ The four issues are introduced in part 2 of this article. The introduction takes the form of a brief explanation of the conflicting views expressed by international scholars and foreign courts in respect of each issue. In the next part of the article, three South African reported judgments are analysed in order to ascertain the courts' view in respect of these issues. The article concludes in part 4 with findings on how these judgments aid the application and interpretation of general renvoi clauses in South African DTAs.

\section{Issues regarding the application and interpretation of general renvoi clauses considered in this article}

\subsection{The ambulatory versus static approach}

In broad terms, article 3(2) provides that an undefined term in a DTA shall have the meaning that it has under the domestic law of the contracting state applying the DTA. In situations where the meaning in the domestic law changed after the DTA had been concluded, the issue arises as to which domestic meaning must be taken into account under this general renvoi clause: the meaning that existed when the DTA was concluded (a static approach), or the meaning that existed when the DTA was applied (an ambulatory approach)? These situations are not rare occurrences, given the fact that most states amend their domestic tax laws far more frequently than they renegotiate their DTAs.

UN MC" 206 m.nr. 109; Avery Jones "Treaty Interpretation" para 4.3.1. Accordingly, Rust "Article 3(2) OECD and UN MC" 206 m.nr. 109 argues that treaty negotiators probably have the meanings under these domestic laws in mind when they are negotiating the treaty.

Avery Jones et al 1984 BTR (I) 16.

It is acknowledged that there are many other aspects relating to the interpretation of undefined terms in DTAs and general renvoi clauses themselves that are central to the process of giving meaning to these undefined treaty terms and general renvoi clauses. It is also acknowledged that there are other issues pertaining to general renvoi clauses that are especially relevant from a South African perspective. Gutuza 2016 SA Merc LJ 497, for example, raises questions regarding the interaction between these clauses and s 233 of the Constitution of the Republic of South Africa, 1996. Also see Du Toit and Hattingh "Beneficial Ownership" para 9.13. 
Since 1995, article 3(2) has made it clear that the relevant domestic meaning is the meaning "at that time"; that is, at the time of application of the DTA. If a DTA includes a post-1995 version of the general renvoi clause,${ }^{9}$ it is thus clear that an ambulatory approach should be taken. There are, however, still a substantial number of DTAs, including DTAs concluded by South Africa, that include a pre-1995 version of the general renvoi clause and that accordingly do not expressly prescribe either the static or the ambulatory approach. ${ }^{10}$ In respect of these DTAs the question thus remains whether the static or the ambulatory approach should be adopted.

According to Du Toit and Hattingh, the static approach was the approach prescribed under "the international law of treaties" in the period prior to the 1995 amendment of article 3(2). ${ }^{11}$ There was also foreign case law in support of the static approach during this period, notably the Canadian case of $R v$ Melford Development Inc (Melford Development)..$^{12}$ One of the main arguments in favour of the static approach in preference to the ambulatory approach is that the latter may give a contracting state the ability to change the effect of a DTA by amending the meaning of a term under its domestic law.

In contrast, there is also support for the ambulatory approach in respect of general renvoi clauses based on the pre-1995 version of article 3(2) in a number of foreign decisions ${ }^{13}$ and scholarly writings. ${ }^{14}$ The Commentaries to the OECD MTC (the Commentaries) have also stated since 1992 (thus after the Canadian decision in Melford Development mentioned earlier, but before the 1995 amendment to article 3(2) of the OECD MTC) that the ambulatory approach was the correct approach. ${ }^{15}$

This refers to a clause based on the wording of art 3(2) of the OECD MTC after its amendment in 1995. Reference elsewhere in this article to the "pre-1995 version" of the general renvoi clause refers to clauses based on the wording of art 3(2) before its amendment in 1995.

10 Du Toit and Hattingh "Beneficial Ownership" para 9.3 n 16.

11 Du Toit and Hattingh "Beneficial Ownership" para 9.3 n 16.

$12 R v$ Melford Development Inc 82 DTC 6281, discussed by Avery Jones et al 1984 BTR (I) 27-28 and 42-43; and Baker Double Taxation Conventions para E.23. See the cases mentioned in Baker Double Taxation Conventions para E.24 and Avery Jones "Treaty Interpretation" para 4.8.2.

$14 \quad$ Wattel and Marres 2003b Euro Tax 223; Baker Double Taxation Conventions para E.25; Avery Jones "Treaty Interpretation" para 4.8.3. Also see Rust "Article 3(2) OECD and UN MC" 211 m.nr. 118 (where he states that there is "nearly a unanimous consensus" in this regard), and $214 \mathrm{~m} . n \mathrm{n} .129$. For a discussion of the positions in various countries and those taken by various scholars, see Avery Jones et al 1984 BTR (I) 42-46.

15 Paragraph 11 of the Commentary to art 3, as it read from 23 July 1992. Since the Commentaries are not binding, however, this cannot be considered the final word in this regard. For the status of the Commentaries from a South African perspective, see Du Plessis 2012 SA Merc LJ; Du Plessis 2016 TSAR; and Burt 2017 BTCLQ. For the status of the Commentaries from an international perspective, see Avery 
One of the arguments in favour of the ambulatory approach is that it may be too cumbersome to go back to "old law" continually, ${ }^{16}$ especially since DTAs typically have such long lifespans. Furthermore, if changes are made to the scope of a domestic tax liability after the conclusion of a DTA, the distributive rule in the DTA will follow the scope of the domestic tax liability only if an ambulatory approach is adopted. However, if the static approach is used in preference to the ambulatory approach, applying the limitation imposed under the DTA on a contracting state's right to tax a particular income stream may become problematic. ${ }^{17}$ Moreover, it might have been the intention of the contracting states when concluding the DTA that the meaning would change as domestic laws change, again in the context of DTAs' long lifespan. ${ }^{18}$ Lastly, the concern mentioned earlier that under the ambulatory approach a contracting state may change the effect of a DTA by amending its domestic law is addressed by the qualification in article 3(2) that the context may require that the amended domestic meaning not be used. Avery Jones thus argues that, when the amendment to the domestic meaning is aimed at enlarging the taxing jurisdiction of the contracting state making that amendment, the context may require that the amended domestic meaning not be used. ${ }^{19}$

As a matter of practice in South Africa, the South African tax collecting authority "tended to" follow the ambulatory approach already as early as in 1993, thus before the 1995 amendment to article 3(2) of the OECD MTC. ${ }^{20}$

In part 3 this article considers whether South African case law has indicated a preference for the one approach over the other in respect of general renvoi clauses based on the pre-1995 version of article 3(2).

Jones "Treaty Interpretation" paras 3.10-3.12. Another issue is whether amendments to the Commentaries made after the conclusion of a DTA should be taken into account when the DTA is interpreted. The issue is relevant with regard to those DTAs that were concluded before the 1992 amendment to the Commentary mentioned in the main text. The issue is not addressed here, but is considered from an international perspective by Wattel and Marres 2003b Euro Tax 224-233; Linderfalk and Hilling 215 Nord Tax J 49-58; and Avery Jones "Treaty Interpretation" para 3.12. Avery Jones et al 1984 BTR (I) 41. Also see Wattel and Marres 2003a Euro Tax 71; Wattel and Marres 2003b Euro Tax 223; Rust "Article 3(2) OECD and UN MC" 211 m.nr. 118.

Rust "Article 3(2) OECD and UN MC" 211 m.nr. 118. Avery Jones et al 1984 BTR (I) 41 add to this that DTAs will have to be amended more frequently if the static approach is followed.

18 Baker Double Taxation Conventions para E.25.

19 Avery Jones "Treaty Interpretation" para 4.6. Also see Avery Jones et al 1984 BTR (I) 40 and 48; Rust "Article 3(2) OECD and UN MC" 211 m.nrs. 118 and 119 and 213 m.nr. 124.

Eskinazi "Interpretation of Double Taxation Conventions" 553. 


\subsection{The use of a different expression in the domestic law}

Article 3(2) provides that an undefined ${ }^{21}$ treaty "term" shall have the meaning that "it" has under the domestic law of the contracting state applying the treaty. Due to the fact that the OECD MTC serves as the basis for DTAs entered into by many different states, each with its own unique domestic tax legislation, the OECD MTC in many instances uses terms "of a wide nature". 22 There is then often a divergence between the wide terms used in DTAs and the expressions used in the domestic (tax) law of the states that use the OECD MTC as the basis for the negotiation of their DTAs. ${ }^{23}$

This gives rise to the following question: if an expression other than the treaty term is used in the domestic (tax) law, can the meaning of that expression in the domestic law be taken into account for the purposes of the general renvoi clause? The controversy lies in how the word "term" in article 3(2) should be interpreted - in particular whether it should include a "concept".24 Some scholars support this possibility and argue that the meaning of a different but comparable expression in the domestic law may thus be taken into account under article 3(2). ${ }^{25}$ However, this view is not shared by all, ${ }^{26}$ based on a more restrictive interpretation of the word "term".

In part 3 below the article considers whether South African courts have taken a view on this issue. However, it must be emphasised that, even if the meaning of a different expression in the domestic law may indeed be taken into account under article 3(2), the treaty term will ultimately be given that domestic meaning only if the qualifications mentioned in part 2.4 below are met.

21 Article 3(2) finds application only if a treaty term is "not defined" in the DTA. This criterion gives rise to its own interpretational issues, as mentioned by Kandev 2007 Can Tax J 40 and Avery Jones "Treaty Interpretation" para 4.3.2.2. Also see the view of Mooij 2019 BTR 26 in respect of the meaning of the phrase. Commissioner for the South African Revenue Service v Tradehold Ltd 20123 All SA 15 (SCA) para [18]. Commissioner for the South African Revenue Service v Tradehold Ltd 20123 All SA 15 (SCA) para [18].

Pijl 1997 BFIT 542. Also see Avery Jones "Treaty Interpretation" para 4.3.2.1.

25 Déry and Ward "Interpretation of Double Taxation Conventions" 277; Pijl 1997 BFIT 542; Wattel and Marres 2003a Euro Tax 71; Engelen Interpretation of Tax Treaties 488; Avery Jones "Interaction between Tax Treaty Provisions and Domestic Law" 133-134; De Broe International Tax Planning and Prevention of Abuse 268; Avery Jones and Hattingh 2016 BTR 427; Avery Jones "Treaty Interpretation" para 4.3.2.1. For support in case law, see the cases discussed by Kandev 2007 Can Tax J 56-57; and Avery Jones "Treaty Interpretation" para 4.3.2.1.

26 See the sources mentioned by Edwardes-Ker Tax Treaty Interpretation 83-84 and Pijl 1997 BFIT 542-543. In 1984, Avery Jones et al 1984 BTR (I) 20-21 concluded that there was not enough authority to draw conclusions in this regard. 


\subsection{The use of deeming provisions in domestic law}

Legislation often includes deeming provisions that give terms that appear in that legislation a meaning different from their usual (ordinary) meaning. The question that arises in the context of general renvoi clauses is whether deeming provisions that give meaning to terms in domestic legislation may also give meaning to treaty terms under general renvoi clauses.

The main concern raised against this possibility is that deeming provisions may "neutralise" the application of a DTA by enabling treaty override in some circumstances, in that they may extend the tax jurisdiction of a contracting state. ${ }^{27} \mathrm{~A}$ number of scholars and foreign courts have nevertheless supported the possibility that deeming provisions may be taken into account under the general renvoi provision. ${ }^{28}$

In part 3 below, the article considers whether South African courts have been prepared to take deeming provisions into account under general renvoi clauses. Here, too, it is important to emphasise that, even if the answer is that deeming provisions may be taken into account, the question whether the treaty term will in fact be given the deemed domestic meaning remains subject to the qualifications discussed in part 2.4 below.

\subsection{The domestic meaning as a "last resort" or as the "leading principle"}

Article 3(2) provides that a domestic meaning "shall" apply to give meaning to a treaty term "unless the context otherwise requires". ${ }^{29}$ Many issues arise with regard to the application and interpretation of this phrase. ${ }^{30}$ The issue

27 Gutuza 2016 SA Merc LJ 501. Also see Gutuza 2008 SALJ 517. Note further the warning by Mooij 2019 BTR 28 that "[t]reaty terms that in negotiations look harmless may in practice, as a result of domestic definition, turn out to have very different meanings". This comment was made in response to the majority's finding in Fowler $v$ The Commissioners for Her Majesty's Revenue and Customs [2018] EWCA Civ 2544, where the UK Court of Appeal interpreted the UK-SA DTA. The majority in that case held that a deeming provision in UK domestic tax law had to be taken into account when interpreting that DTA. The majority referred at paras [42] and [47] to the general renvoi clause in the DTA.

28 Pijl 1997 BFIT 543; De Broe International Tax Planning and Prevention of Abuse 285. For examples of foreign case law in favour of this possibility, see the UK case referred to in the previous footnote and the Dutch case law discussed by De Pietro 2015 World Tax J para 3.1 and Kandev 2007 Can Tax J 54-55, as well as the Canadian case discussed by the latter at 53-54.

29 In 2017 a further qualification was added to art 3(2) of the OECD MTC. This reads as follows: "or the competent authorities agree to a different meaning pursuant to the provisions of Article 25".

30 For example, it may be asked which factors are relevant when making this determination. There is probably a wide range of such factors, as discussed by Avery Jones "Treaty Interpretation" para 5.1. Another issue concerns the meaning of 
considered in this article is whether the approach of giving an undefined term in a treaty its meaning under domestic law in terms of a general renvoi clause is only "a last resort" or "the leading principle". ${ }^{31}$

A number of scholars support the "last resort" view. ${ }^{32}$ They argue that one should not overemphasise the use of the words "shall" and "require" in article 3(2). Rather, the context and purpose of the DTA should take more prominence. ${ }^{33}$ Therefore, a DTA "must be interpreted from its own meaning and context [and] [o]nly if this does not yield an answer can one reach to domestic law as an interpretation aid."34 One of the fears in this regard is that the adoption of divergent domestic law meanings may result in one of the objects of DTAs, being the granting of relief against international juridical double taxation, not being achieved. The argument is that, should the source and resident states adopt divergent domestic law meanings with regard to the distributive rules provided for under the DTA, this might result in a conflict in the qualification of income. As a result, both states may tax the income, each under a different distributive rule, with the resident state refusing to grant tax relief in respect of the tax levied by the source state. ${ }^{35}$

"context" for the purposes of this clause, as discussed by Edwardes-Ker Tax Treaty Interpretation 76-79 and Avery Jones "Treaty Interpretation" para 5.1. These phrases are adopted by Mooij 2019 BTR 25-26 and Kandev 2007 Can Tax J $\mathrm{n} 29$. This issue forms part of the wider topic of the interaction between the provisions dealing with the interpretation of treaties in the Vienna Convention on the Law of Treaties (VCLT) and art 3(2), as discussed by Kandev 2007 Can Tax J 38-39. Mooij 2019 BTR 25 and see the sources listed by Avery Jones et al 1984 BTR (II) 105-106; Edwardes-Ker Tax Treaty Interpretation 80-83; and Kandev 2007 Can Tax Jn 29.

See the summary of this argument by Kandev 2007 Can Tax J 39.

Debatin and Walter, as quoted by Edwardes-Ker Tax Treaty Interpretation 80, but see Avery Jones "Treaty Interpretation" para 5.1.2.2.6. Mooij 2019 BTR 25, for example, argues that "[t]reaty policies should aim at matching countries' different domestic tax rules with each other rather than preserving the domestic rules as much as possible, and treaty interpretation should aim to do likewise .... Treaties do not intend to preserve a right for countries to retain their own domestic definitions". Take the following example: the source state interprets the DTA based on the meaning that an undefined term in the DTA has in its domestic law. As a result, the income falls within a distributive rule that grants the source state the concurrent right to tax that income. The resident state in turn interprets the DTA according to the meaning that that term has in its domestic law. Under this interpretation, the income falls within a different distributive rule, which grants it (the resident state) the exclusive right to tax the income. In this scenario, there is thus the possibility that both states will tax the income. Furthermore, the resident state may refuse to grant tax relief under either art 23A or art 23B of the OECD MTC since the source state had no right to tax the income in the first place, based on the resident state's interpretation of the DTA. The result may thus be international juridical double taxation. 
Proponents of the "leading principle" view place emphasis on the wording of article 3(2). They argue that the words "shall"36 (instead of "may") and "requires" 37 indicate a preference for the domestic meaning that can be dislodged only if there are "reasonably strong" arguments to the contrary. ${ }^{38}$ With reference to the fear that international juridical double taxation may arise if divergent domestic meanings are adopted by the resident and source states, they point out that this risk has now fallen away "in nearly all instances" due to the development of a different understanding of the resident state's obligation to give tax relief under article 23A or article 23B. ${ }^{39}$ Under this understanding, the resident state is obliged to give tax relief in respect of taxes levied by the source state in those instances where it and the source state adopted different meanings for a treaty term due to divergent domestic meanings. ${ }^{40}$ The risk of international juridical double taxation is thus reduced under this view.

Avery Jones, who is a supporter of the "leading principle" view, notes that article $3(2)$ is not the only provision in the OECD MTC that includes the

36 Van der Bruggen 2003 Euro Tax 153; Kandev 2007 Can Tax J 38; Olivier and Honiball International Tax 544. Also see Avery Jones 2019 BTR 24.

37 Avery Jones et al 1984 BTR (II) 108 proposes that it is a word "of some force".

38 Avery Jones et al 1984 BTR (II) 108. Van der Bruggen 2003 Euro Tax 153 notes that "the discordance" must be "sufficiently clear". Rust "Article 3(2) OECD and UN MC" 212 m.nr. 123 notes that "weighty arguments" should be put forward if the domestic meaning is not used and see 212 m.nr. 122. At 212 m.nr. 123 Rust concludes that "interpretation contrary to the meaning a term has under domestic law must constitute an exception". Castro 2014 Intertax 715 argues that "strong arguments" are necessary to depart from a domestic meaning. Avery Jones "Treaty Interpretation" para 5.1.1 notes that "there must be a good reason to displace the ... domestic law meaning ... This means that a higher threshold than the balance of probabilities will prevail to displace the ... domestic law meaning". Avery Jones 2019 BTR 24 argues that "one starts and finishes with Article 3(2)". Also see De Broe International Tax Planning and Prevention of Abuse 277; Kandev 2007 Can Tax J 68; as well as the sources listed by Edwardes-Ker Tax Treaty Interpretation 81-82.

39 Rust "Article 3(2) OECD and UN MC" 206 m.nr. 109. However, Avery Jones "Treaty Interpretation" para 4.7.1 points out that some counties do not adhere to the view set out in the main text and that not all DTAs follow the current wording of art $23 \mathrm{~A}$ and art 23B of the OECD MTC. Also see Baker Double Taxation Conventions para E.21.

40 Under this view, the resident state is obliged to accept the source state's interpretation and grant relief under either art 23A or art 23B. Also see Kandev 2007 Can Tax J 38; Rust "Article 3(2) OECD and UN MC" 209-210 m.nrs. 118-210 and 211 m.nr. 120; and Avery Jones "Treaty Interpretation" para 4.7.1. Para 32.3 of the Commentary to art $23 \mathrm{~A}$ and $23 \mathrm{~B}$ currently provides as follows: "Where, due to differences in the domestic law between the State of source and the State of residence, the former applies, with respect to a particular item of income or capital, provisions of the Convention that are different from those that the State of residence would have applied to the same item of income or capital, the income is still being taxed in accordance with the provisions of the Convention, as interpreted and applied by the State of source. In such a case, therefore, the two Articles require that relief from double taxation be granted by the State of residence notwithstanding the conflict of qualification resulting from these differences in domestic law." 
qualification "unless the context otherwise requires". A similar qualification is also included in article 3(1), which contains a list of definitions applicable to the OECD MTC. Avery Jones argues that the reasons that would be required to overthrow a definition of a term under article 3(1) might have to be stronger than those required to overthrow a domestic meaning under article 3(2). The basis for his argument is that it is far less certain that the treaty negotiators agreed upon the domestic meaning than that they agreed upon a definition in article 3(1). ${ }^{41}$

In part 3 this article considers whether South African case law is leaning towards an approach whereby treaty terms are given their meaning under domestic law in terms of general renvoi clauses only as a matter of "last resort", or whether such an approach is "the leading principle".

\section{South African case law in which reference was made to the general renvoi clauses in South African DTAs}

There have been occasions where a South African court has given an undefined term in a DTA the meaning that it has in South African domestic tax law without referring to the general renvoi clause in the applicable DTA. ITC $1878^{42}$ is such an example. In this case, the court considered the South Africa-United States (US) DTA. One of the issues that arose was the interpretation of the following phrase in that DTA:43

\section{for a period or periods aggregating more than 183 days in any twelve-month} period commencing or ending in the taxable year concerned.

The OECD MTC and Commentaries, ${ }^{44}$ which the court consulted, use the expression "fiscal year" instead of "taxable year", but the court did not attach any importance to this difference in terminology. The term "fiscal year" is not defined in the OECD MTC and the OECD has proposed that its meaning be determined in accordance with article 3(2). ${ }^{45}$ It is not used in the South African Income Tax Act (ITA), ${ }^{46}$ and neither is the term "taxable year". The court in ITC 1878 accepted without explanation that the "fiscal year" of the taxpayer, a non-resident company, ran from 1 March to 28 February. ${ }^{47}$ This, of course, is the "year of assessment" for individuals, but not necessarily

Avery Jones et al 1984 BTR (II) 94 and Avery Jones 2017 BTR 396.

ITC 1878201577 SATC 349.

Article 5(2)(k) of the 1997 South Africa-US DTA (emphasis added), quoted at ITC 1878201577 SATC 349 para [12].

44 The court in this case considered the Commentary pertaining to art 15 of the OECD MTC.

45 OECD $1991 \mathrm{http}: / / \mathrm{dx}$. doi.org/10.1787/9789264239081-102-en para 21. Also see Pötgens Income from International Private Employment 563; Arnold 2008 BFIT 224.

$46 \quad$ Income Tax Act 58 of 1962 (ITA).

47 ITC 1878201577 SATC 349 para [47], where the court referred to this period as the "tax year". 
companies. ${ }^{48}$ As pointed out above, the court did not refer to the general renvoi clause, but it is nevertheless noteworthy that the court used a domestic meaning for a different term ("year of assessment") to give meaning to the treaty term ("taxable year").

Considered below are three judgments in which a South African court was tasked with the interpretation of a DTA and the court expressly referred to the general renvoi clause in that DTA.

\title{
3.1 ITC 789
}

ITC $789^{49}$ concerned non-resident shareholders' tax (NRST) levied under 1941 income tax legislation of the Union of South Africa (1941 ITA). ${ }^{50}$ The South Africa-United Kingdom (UK) DTA, signed in October 1946, included the following exemption from NRST: ${ }^{51}$

\begin{abstract}
There shall be exempt from the Union non-resident shareholders' tax - (a) any amount in respect of which the person chargeable with such tax is a company, if the amount so chargeable represents the whole or a portion of the taxable income of a private company which, under the law of the Union relating to the taxation of the income of private companies, is apportionable ... to a public company which is a resident of the United Kingdom.
\end{abstract}

The case concerned a private company that had a portion of its taxable income apportioned "under the law of the Union" to its UK shareholder. The court in ITC 789 had to determine whether the UK shareholder qualified as a "public company" for the purposes of the above-mentioned exemption under the DTA.

The term "public company" was defined in the 1941 ITA. ${ }^{52}$ The parties and the court accepted that the term in the treaty would have the meaning set out in this definition and the court noted that this was "placed beyond doubt" by the general renvoi clause in the 1946 South Africa-UK DTA. ${ }^{53}$ The court held that the UK resident company did not meet that definition in the 1941 ITA and that the exemption in the DTA accordingly did not apply. ${ }^{54}$

At first glance, the judgment in ITC 789 does not add much to an understanding of the interpretative issues surrounding general renvoi

48 See the definitions of "financial year" and "year of assessment" in s 1 of the ITA, read with $s 5(1)(c)$ and $(d)$.

$49 \quad$ ITC 789195419 SATC 434 (ITC 789).

50 Income Tax Act 31 of 1941 (the 1941 ITA).

51 Article $\mathrm{VI}(1)(\mathrm{a})$ of the 1946 South Africa-UK DTA (emphasis added), quoted at ITC 789 436-437.

52 Section $33(2)$ of the 1941 ITA.

$53 \quad$ ITC 789 437. Also see Baldwins (South Africa) Ltd $v$ Commissioner for Inland Revenue 196124 SATC 270 281. The general renvoi clause was art II(3) of the 1946 South Africa-UK DTA.

54 ITC 789441. 
clauses highlighted in part 2. However, it may be of some interest to the issue identified in part 2.1, that is whether the ambulatory or statutory approach should be followed in respect of general renvoi clauses based on the pre-1995 version of article 3(2). The general renvoi clause considered in ITC 789 was such a clause. In this regard, it is noteworthy that certain provisions of the 1941 ITA relating to the taxation of the income of private companies were changed after the conclusion of the 1946 South Africa-UK DTA. As noted above, the NRST exemption in the DTA applied in respect of 55

any amount ... which, under the law of the Union relating to the taxation of income of private companies, is apportionable ... to a public company.

This provision thus did not expressly state whether, for the purposes of this exemption, the law pertaining to the taxation of the income of private companies applied as at the conclusion of the DTA, or as at the application of the DTA. The taxpayer conceded that ${ }^{56}$

'the law of the Union relating to the taxation of the income of private companies' includes any alteration of that law introduced subsequent to the date of the $[D T A]$.

The court expressly agreed with this view. ${ }^{57}$

The phrase "under the law of the Union relating to" in this exemption from NRST is comparable with the phrase in the general renvoi clause in the DTA, which stated that undefined terms in the DTA should have the meaning "under the laws of that Contracting Government relating to the taxes". ${ }^{58}$ It is not surprising that the exemption from NRST should mirror any changes in the domestic tax law with regard to the manner of calculating the amounts subject to NRST. One thus cannot infer from this alone that the general renvoi clause would have been interpreted in the same ambulatory manner. The correlation in the wording of the NRST exemption and the general renvoi clause is nevertheless noteworthy and the court's approach at least indirectly shows that it was not averse to adopting an ambulatory approach.

\footnotetext{
$55 \quad$ Emphasis added.

$56 \quad$ ITC 789437.

$57 \quad$ ITC 789437.

58 The relevant part of the 1963 version of art 3(2) of the OECD MTC reads as follows: "which it has under the laws of that Contracting State relating to the taxes" (emphasis added). In the 1977 version this phrase was amended, and it has since read as follows: "which it has under the law of that State concerning the taxes" (emphasis added). According to Avery Jones et al 1984 BTR (I) 19 the change from "relating" to "concerning" in the English text of the OECD MTC is unlikely to signify a change in meaning.
} 


\subsection{Baldwins (South Africa) Ltd v Commissioner for Inland Revenue}

The decision by the Appellate Division (AD) in Baldwins (South Africa) Ltd $\checkmark$ Commissioner for Inland Revenue (Baldwins) ${ }^{59}$ also dealt with the NRST exemption in the 1946 South Africa-UK DTA. As in ITC 789,60 the AD had to decide whether a UK company which was the sole shareholder of the South African taxpayer company was a "public company" for the purposes of the NRST exemption in the DTA. One of the issues considered by the court was whether the definition of "public company" in the 1941 ITA could be used to give meaning to the term in the DTA. The taxpayer pointed out that this definition included categories of companies that could apply only to local and not to foreign companies, and argued that this was an indication that it was not the intention of the contracting states that the definition in the 1941 ITA would apply to the NRST exemption in the DTA. ${ }^{61}$ The taxpayer further argued that the meaning of the treaty term "public company" should instead derive from the company laws of either the Union of South Africa ${ }^{62}$ or the UK. According to the taxpayer, this would have resulted in the taxpayer's UK parent company qualifying as a "public company". ${ }^{63}$

The AD disagreed with this argument and noted as follows: ${ }^{64}$

I can find nothing ... which shows clearly that the term 'public company' cannot have the meaning which has been assigned to it in .... our Income Tax Act.... On the contrary there is at least one very good reason why no other meaning should be assigned to it, and that is that otherwise the legislature of the United Kingdom could, by altering its definition of 'public company', alter the incidence of a Union tax in the Union. Such a possibility could never have entered the minds of the two contracting Governments.

Some scholars argue that this statement in Baldwins supports the static approach discussed in part 2.1.65 When evaluating this argument it is

59 Baldwins (South Africa) Ltd v Commissioner for Inland Revenue 196124 SATC 270 (Baldwins).

60 The AD referred to ITC 789 at Baldwins 281.

$61 \quad$ Baldwins 272.

62 It should be pointed out that the general renvoi clause in the 1946 SA-UK DTA did not include the phrase "any meaning under the applicable tax laws of that State prevailing over a meaning given to the term under other laws of that State". This phrase was added to art 3(2) of the OECD MTC only in 1995. The court in Baldwins did not expressly consider the meaning of the word "public company" in the Union's company laws and did not explain why it refrained from doing so. Baldwins 273, 281. As mentioned in the previous footnote, the meaning under the company laws of the Union of South Africa was not considered in the judgment.

64 Baldwins 281 (emphasis added).

65 Du Toit and Hattingh "Beneficial Ownership" para $9.11 \mathrm{n}$ 175. In support of their argument they note as follows: "The Appellate Division refused to apply an amended domestic definition of the term in the United Kingdom since this domestic definition postdated the conclusion of the convention and, if followed through in the convention, would allow the United Kingdom the opportunity to unilaterally alter the allocation of tax relief from a South African tax under the convention." Avery Jones 
important to note that there is no mention in the reported judgment of any actual amendment of either the definition of "public company" in the 1941 ITA or the meaning of "public company" in UK company law in the period after the conclusion of the 1946 DTA and leading up to the years of assessment considered in Baldwins. The statement of the court was thus not made in the context of deciding which of two possible meanings, one existing at the time of the conclusion of the DTA and an amended one existing at the time of the application of the DTA, should be used for the purpose of the DTA's general renvoi clause. Furthermore, it seems that the concern of the AD was aimed mainly at the possibility that, if a domestic meaning from UK law were to be used (as proposed by the taxpayer), the UK could, by amending its legislation, force South Africa to give an exemption from a tax levied by South Africa. There is no indication that the AD would have been equally concerned had South Africa amended its own legislation to extend the circumstances under which it would give exemption from NRST. It thus seems that Baldwins does not add to the debate on the static versus ambulatory approach.

Turning to the phrase "unless the context otherwise requires", the AD in Baldwins referred to a judgment of the Privy Council where that court held as follows: 66

\begin{abstract}
Now, when the interpretation clause in a statute says that such and such an expression shall include so and so, a court in construing a statute is bound to give effect to the direction unless it can be shown that the context of the particular passage where the expression is used shows clearly that the meaning is not in this place to be given effect to, or unless there can be alleged some general reason of weight why the interpretation clause is to be denied its application.
\end{abstract}

The court in Baldwins indicated that it would thus depart from the domestic meaning of "public company" in the 1941 ITA only if the context "clearly" showed otherwise, or if there were some other reasons "of weight". ${ }^{67}$ Also, it was pointed out earlier that Avery Jones argues that the reasons required to overthrow a definition of a term under article 3(1) (which also includes the phrase "unless the context otherwise requires") might have to be stronger than those required to overthrow a domestic meaning under article 3(2). If one takes this argument further, the reasons will have to be stronger to overthrow a statutory definition in domestic legislation when interpreting that legislation ${ }^{68}$ than a domestic meaning under article 3(2) when interpreting a

"Treaty Interpretation" para 4.8.2 notes that the AD in this case "declined to apply later domestic law in the other state". Govindasamy v Indian Immigration Trust Board Natal 1918 AD 633, quoted at Baldwins 281. Emphasis added.

Baldwins 280-281.

It is common for South African legislation when defining terms to include the phrase "unless the context otherwise requires", or a comparable one. S 1 of the ITA, for 
DTA. Amongst other considerations, one should bear in mind that only one legislature is involved in making domestic law as opposed to two in respect of DTAs. ${ }^{69}$ However, in Baldwins the court made no such distinction. Arguably, the court therefore required an equally strong indication that the context required otherwise in the case of both these instruments.

\subsection{Commissioner for the South African Revenue Service $v$ Tradehold}

\subsubsection{Background}

Commissioner for the South African Revenue Service $v$ Tradehold (Tradehold) ${ }^{70}$ concerned the imposition of an "immediate exit tax". An exit tax is a tax that is levied due to the fact that a person has left the tax jurisdiction of a state; that is, upon "tax emigration". ${ }^{71}$ In the case of an immediate exit tax, the taxable amount is calculated with reference to the value of the emigrating taxpayer's assets at the point in time immediately prior to the tax emigration. ${ }^{72}$ The tax is levied even though no actual transfer of assets took place and there is thus no realised gain at that stage.

The taxpayer in Tradehold was a South African incorporated company that relocated its "place of effective management" from South Africa to Luxembourg. According to Gutuza, ${ }^{73}$ the taxpayer thus became simultaneously tax resident in both South Africa and Luxembourg under each state's domestic tax laws. It was tax resident in Luxembourg only for the purposes of the South Africa-Luxembourg DTA, however. ${ }^{74}$

Shortly thereafter, an amendment to the definition of "resident" in the ITA resulted in the fact that the taxpayer ceased to be a tax resident of South

example, includes the phrase "unless the context otherwise indicates". For more recent case law on when a South African court will depart from a definition in domestic legislation see, for example, Canca v Mount Frere Municipality 19842 SA 830 (Tk) 832; SATAWU v Garvas 20131 SA 83 (CC) para 134; and Minister of Mineral Resources $v$ Sishen Iron Ore Co (Pty) Ltd 20142 SA 603 (CC) para [59]. Regarding the meaning of the word "require" in different contexts, see Clutchco (Pty) Ltd $v$ Davis 20053 SA 486 (SCA) paras [11]-[12].

69 As Arnold 2010 BFIT 10 notes, "it is more difficult to determine the intentions of the two parties to a treaty than the intention of a single legislature".

70 Commissioner for the South African Revenue Service v Tradehold Ltd 20123 All SA 15 (SCA) (Tradehold).

71 Chand 2013 BFIT heading 1. Under the ITA, the exit tax is not a separate tax. It refers to an amount that is taken into account when calculating a person's "taxable income" in respect of which normal tax is levied.

$72 \quad$ Chand 2013 BFIT heading 2.1.1.

73 Gutuza 2016 SA Merc LJ 492-493. Also see Anonymous 2012 Taxpayer 95.

74 This was due to the application of the tie-breaker clause in art 4(3) of the South Africa-Luxembourg DTA. The DTA was entered into between South Africa and the Government of the Grand Duchy of Luxembourg on 6 December 2000. 
Africa for the purposes of the ITA too. ${ }^{75}$ The Commissioner argued that at this stage a deeming provision in the Eighth Schedule to the ITA triggered the imposition of the exit tax. ${ }^{76}$ Under this deeming provision, ${ }^{77}$ the taxpayer was "treated ... as having disposed" of its only relevant asset, its shareholding in a subsidiary company.

In response to the Commissioner's argument, the taxpayer argued that South Africa was prevented from levying the exit tax under a provision in the South Africa-Luxembourg DTA that is based on the current article 13(5) of the OECD MTC. ${ }^{78}$ This provision gave the contracting state in which the alienator was resident (Luxembourg, in the case of Tradehold) ${ }^{79}$ the exclusive taxing right in respect of the "alienation" of assets consisting of shares.

To counter this argument, the Commissioner contended that the tax emigration that triggered the exit tax was not an "alienation" as contemplated under the DTA and that the DTA thus did not restrict South Africa's right to levy the exit tax. ${ }^{80}$ The SCA was accordingly left with the task of giving meaning to the word "alienation" in the South AfricaLuxembourg DTA. The word "alienation" is used in article 13 of the OECD MTC to indicate the event that gives rise to the gains covered by each of its sub-paragraphs. ${ }^{81}$ The most common dictionary meaning for the word

75 Definition of "resident" in s 1 of the ITA.

76 The Commissioner argued that the immediate exit tax was triggered either when the taxpayer relocated its place of effective management to Luxembourg, or when it ceased to be a resident of South Africa. Tradehold para 4.

77 At the time of the judgment in Tradehold, this deeming provision was found in para 12(1) and (2)(a) of the Eighth Schedule to the ITA. It has since been removed from the Eighth Schedule and replaced by a new $\mathrm{s} 9 \mathrm{H}$ in the main ITA.

78 Article 13(4) of the South Africa-Luxembourg DTA.

79 Arnold 2012 BFIT 484 explains that, on the assumption that tax emigration may be regarded as an "alienation" in terms of art 13 of the OECD MTC, states often deem in their domestic tax law that the alienation takes place immediately prior to the tax emigration. If this deeming is effective, it results in the taxation event happening at a time when the taxpayer is still resident in the state from which the emigration took place. This would give that state the right to levy an exit tax under the DTA. At the time of the application of the South Africa-Luxembourg DTA in Tradehold, the ITA also contained such a timing provision in para $13(1)(\mathrm{g})$ of the Eighth Schedule. However, in Tradehold this deeming provision did not have the result referred to by Arnold and much speculation ensued amongst scholars as to why this might have been the case. See in this regard Mazansky 2012 BFIT 375; Arnold 2012 BFIT 484; Classen 2013 SA Merc LJ 395-397; Gutuza 2014 SA Merc LJ 552. According to Anonymous 2012 Taxpayer 91, 95, it has to do with the rather unique factual circumstances of the case, including the change in legislation described earlier in the main text. 
"alienation" is "the transfer of ownership". ${ }^{2}$ However, states often include in their domestic tax legislation a definition for the term "alienation", or a definition for a different but comparable term, ${ }^{83}$ and this definition frequently gives the term a meaning that includes events that do not involve a transfer of ownership. ${ }^{84}$

All of the above also holds true for the Eighth Schedule to the ITA. This is the part of the ITA in terms of which provisions relevant to the exit tax, forming part of capital gains tax (CGT), ${ }^{85}$ were included at the time that the South Africa-Luxembourg DTA was applied. Under this part, the trigger event for the levying of CGT is the "disposal" of an asset, rather than its "alienation". The term "disposal" is defined in general terms to include an "event ... which results in the ... transfer ... of an asset". ${ }^{86}$ Certain specific events are also expressly included, such as the "sale ... or any other alienation or transfer of ownership" of an asset. ${ }^{87}$ In addition to this general definition of a "disposal", a number of events are "treated" as disposals. ${ }^{88}$ At the time of the application of the South Africa-Luxembourg DTA, tax emigration was one such event.

The question considered in Tradehold was thus whether tax emigration, which involves no actual transfer of assets, can be regarded as an "alienation" for the purposes of a provision in a DTA based on the current article $13(5)$ of the OECD. This question had been considered prior to Tradehold by foreign courts. The Dutch Hoge Raad, for example, ${ }^{89}$ had considered it in respect of a Dutch exit tax on substantial shareholding. ${ }^{90}$ In terms of the relevant Dutch tax legislation, tax emigration from the Netherlands was deemed a "vervreemding" and triggered the imposition of the Dutch exit tax. ${ }^{91}$ The Hoge Raad had to consider provisions in three

82 Simontacchi Taxation of Capital Gains 175. Also see the dictionary meaning of "alienation" mentioned at Tradehold para [13].

83 Simontacchi Taxation of Capital Gains 180.

84 Simontacchi Taxation of Capital Gains 178-179.

85 See $\mathrm{n} 71$ above, which also pertains to "capital gains tax".

86 The definition of "disposal" in para 1, read with para 11(1), of the Eighth Schedule to the ITA.

87 Paragraph 11(1)(a) of the Eighth Schedule to the ITA (emphasis added). To complete the definition of a "disposal", para 11(2) of the Eighth Schedule lists a number of events that do not constitute a "disposal".

88 Paragraph 12 of the Eighth Schedule to the ITA.

89 Apart from the example mentioned in the main text, see the Canadian case law discussed by Kandev 2007 Can Tax J 57-58 and the German case law referred to by Chand 2013 BFIT n 145.

90 Decision by the Hoge Raad (20 February 2009) 42701 BNB 2009/260; Decision by the Hoge Raad (20 February 2009) 43760 BNB 2009/261; Decision by the Hoge Raad (20 February 2009) 07/12314 BNB 2009/262. Also see the discussion of these cases by De Pietro 2015 World Tax J 83.

91 Section 4.16 of the Wet op de inkomstenbelasting 2001 is introduced by the title "Fictieve vervreemdingen". The section states: "Onder vervreemding van aandelen 
Dutch DTAs, each based on the current article 13(5) of the OECD MTC. ${ }^{92}$ The court was primarily concerned with the question whether the levying of the exit tax, which had been introduced after the conclusion of the respective DTAs, constituted treaty override. However, the court referred to the general renvoi clauses included in these DTAs and held that the deemed vervreemding constituted an "alienation" under the treaties. ${ }^{93}$

Scholars, too, have considered whether tax emigration that triggers an exit tax can constitute an "alienation" for the purposes of article 13. Some scholars support this possibility. They contend that the treaty term "alienation" has a wide, autonomous meaning that includes tax emigration. Alternatively (or additionally) they contend that this outcome is achieved by referring to the domestic meaning of the term as provided for in the general renvoi clause. ${ }^{94}$ These scholars also argue that the Commentary pertaining to article 13 supports their view. ${ }^{95}$ There are, however, authors that argue against this possibility. ${ }^{96}$

of winstbewijzen wordt mede verstaan...(h) het anders dan door overlijden ophouden binnenlands belastingplichtige te zijn, hieronder begrepen de situatie waarin de belastingplichtige voor de toepassing van de Belastingregeling voor het Koninkrijk, de Belastingregeling voor het land Nederland of een verdrag ter voorkoming van dubbele belasting wordt geacht geen inwoner van Nederland meer te zijn." For a summary of the main elements of the Dutch exit tax on substantial shareholding, see Chand 2013 BFIT heading 2.1.4. At the time of entering into these DTAs, art 13(4) of the OECD MTC was the comparable provision.

93 As summarised by De Pietro 2015 World Tax J 83-84.

94 Simontacchi Taxation of Capital Gains 184, 191 and 196 argues that the treaty term "alienation" should be interpreted as having a wide meaning that could include tax emigration, but that recourse to art 3(2) may at times be needed. Arnold 2012 BFIT 483 also argues in favour of the use of art 3(2).

The passages most often relied on are paras 7-9 and para 10. In respect of paras 79 of the Commentary, see the conclusie by Advocate General Wattel to the Decision by the Hoge Raad (20 February 2009) 42701 BNB 2009/260 paras 4.13 and 4.43; Simontacchi Taxation of Capital Gains 186-187; Arnold 2012 BFIT 483 (who refers to paras 5-8); Chand 2013 BFIT heading 4.3.1; Mooij 2019 BTR 25 (who refers to para 8). In respect of para 10 of the Commentary, see Simontacchi Taxation of Capital Gains 192-193; Brilman 2015 BFIT 446.

De Broe "Tax Treatment of Transfer of Residence by Individuals" 65 argues that "§§6-10 of the OECD commentary on article 13 OECD model do not support the view that countries are entitled to tax unrealized gains that accrued prior to emigration". Arnold 2012 BFIT n 13 also notes: "M. Lang, Introduction to the Law of Double Taxation Conventions pp. 100-101 (Linde 2010) takes the view that 'alienation' should have a treaty meaning independent of domestic law and therefore, deemed dispositions under domestic law are not necessarily alienations under a tax treaty." Also see the other sources mentioned by Chand 2013 BFIT n 138. 


\subsubsection{The court's finding on the application of the general renvoi clause}

The tax court ${ }^{97}$ in the Tradehold matter held that the deemed disposal constituted an "alienation" under the DTA. It never mentioned the general renvoi clause in the South Africa-Luxembourg DTA, but stated as follows: ${ }^{98}$

I am unable to see any reason why a deemed disposal of property should not be treated as an alienation of property for purposes of ... the DTA. I agree in this regard with counsel for the appellant, who argued that it would be absurd if a taxpayer were to be protected in terms of ... [the DTA] from liability for tax resulting from a gain from an actual alienation of property, but not from a deemed alienation of property.

On appeal, the SCA referred to two arguments advanced by the Commissioner in averring that no "alienation" as contemplated in the DTA had taken place. ${ }^{99}$ The first argument was that, since tax emigration is a deemed disposal under the South African ITA, it cannot be regarded as an actual disposal and thus also not as an "alienation" under the DTA. The Commissioner's second argument was that "alienation" should have the meaning that it (and not the term "disposal") would have under South African non-tax law, bearing in mind that the word "alienation" itself is not defined in the ITA; ${ }^{100}$ in this context, "alienation" does not include tax emigration. ${ }^{101}$

$97 \quad$ ITC 1848201073 SATC 170.

98 ITC 1848201073 SATC 170 paras [14] and [15]. These, and the next paragraph of the judgment, were quoted by the SCA in its judgment at para [10].

$99 \quad$ Tradehold paras [11]-[13].

100 As pointed out in $\mathrm{n} 62$ above, in some cases where an undefined treaty term is interpreted there may be conflicting domestic meanings. This gives rise to uncertainty as to how the appropriate domestic meaning should be determined (although, after 1995, art 3(2) deals with this potential issue more explicitly). In other cases there may not be a domestic meaning at all in the tax legislation (or in the part of the tax legislation relating to the levying of the tax that is restricted under the DTA), but there may be a meaning in other areas of the domestic (tax) law. The question is whether art 3(2) can be applied in these cases. Both these issues are considered by Kandev 2007 Can Tax J, Rust "Article 3(2) OECD and UN MC" 207-208 m.nr. 112 and Avery Jones "Treaty Interpretation" para 4.4. There is, however, no indication that the SCA in Tradehold was troubled by these issues, since it only briefly mentioned at para [13] the Commissioner's contention that "alienation" should have the meaning that it has in the context of insolvency law, discussed in the next footnote.

101 There is case law on the meaning of the term "alienation" in the context of South African insolvency legislation. The court in Cronje $v$ Paul Els Investments (Pty) Ltd 19822 SA 179 (T) 188 defined it as "die handeling waardeur eiendomsreg oorgedra word". This meaning was, in turn, based on an earlier decision by the AD in Grobler $v$ Trustee Estate De Beer 1915 AD 265, where too insolvency legislation was considered. This meaning thus corresponds with the dictionary meaning of the word mentioned in the main text corresponding to $\mathrm{n} 82$, that is, "the transfer of ownership". There are also South African non-tax statutes that contain definitions for "alienate" and "alienation" respectively. Examples include the definitions for "alienate", with "alienation" having a "corresponding meaning", in s 1(1) of the Alienation of Land Act 68 of 1981 and s 1 of the Property Time-Sharing Control Act 75 of 1983. The Housing 
The court rejected the Commissioner's argument and held that South Africa was prohibited from imposing the exit tax in these circumstances under the DTA. ${ }^{102}$ In order to analyse the judgment of the SCA in the light of the issues raised in part 2 of this article, one must first determine which of the following two alternatives played out in the SCA's judgment: the SCA gave the treaty term "alienation" the meaning that it (or a comparable term) has in South African domestic law under the general renvoi clause included in the South Africa-Luxembourg DTA; alternatively, the SCA gave the treaty term "alienation" an autonomous meaning that includes tax emigration. Which of these alternatives is the more likely one is discussed next by analysing various statements made by the SCA and scholars' understanding of the SCA's judgment.

The first statement of the SCA worth noting is the following statement: ${ }^{103}$

The [South Africa-Luxembourg] DTA is based upon the [OECD MTC], which has served as the basis for similar agreements that exist between many countries. In interpreting its provisions, one must therefore not expect to find an exact correlation between the wording in the DTA and that used in the domestic taxing statute... [I] nevitably the wording in the DTA cannot be expected to match precisely that used in the domestic taxing statute. In SIR $v$ Downing (supra) Corbett JA remarked ... 'The convention makes liberal use of what has been termed "international tax language" (see Ostime ...)' ... . Sub-article 2 [of article 3] provides for a general rule of interpretation for terms used in the DTA that are not defined. 'Alienation' is not one of the defined terms and thus article 3(2) finds application ...

In a later statement, the SCA held as follows: ${ }^{104}$

The crisp question that falls to be determined is whether the term 'alienation' as used in the DTA includes within its ambit gains arising from a deemed (as opposed to actual) disposal of assets. As mentioned above ${ }^{105}$ the term must be given a meaning that is congruent with the language of the DTA having regard to its object and purpose.

Classen argues that the court "relied heavily" on article 3(2), ${ }^{106}$ which presumably means that her view is that the court gave a domestic meaning to the treaty term "alienation". Du Plessis, however, favours the view that a domestic meaning was not given to the treaty term. She argues that the court by implication held that the context required that a domestic meaning

Development Schemes for Retired Persons Act 65 of 1988 has a definition for "alienate" in $\mathrm{s} 1$. None of these statutes was mentioned in Tradehold.

Tradehold para [25].

Tradehold paras [18]-[19] (emphasis added).

Tradehold para [23] (emphasis added).

Tradehold para [21].

Classen 2013 SA Merc LJ 398-399. She argues, however, that the facts perhaps warranted that the context required an alternative interpretation. 
not be used ${ }^{107}$ and that the SCA gave the treaty term an autonomous meaning that includes tax emigration. In support of her view, she points out that the SCA referred to the use of "international tax language" in DTAs in the passage quoted above. ${ }^{108}$

With regard to the phrase "international tax language", Prokisch explains that it refers to the "common international understanding" of a treaty term. He further argues that, by using this term in a DTA, the contracting parties to that DTA intend for the term to have that meaning, ${ }^{109}$

unless they prefer to give the term a special meaning, either by formulating a special definition of the term or by using a term which has a clear relation to domestic law.

Prokisch's explanation opens up a number of possibilities relating to the motivation for including a widely-used term in a DTA. Two of these are relevant here. The first is that the contracting parties elected that treaty term in order to convey that the "common international understanding" for that term should apply to their DTA. The second possibility is that the treaty term has "a clear relation" to a term used in the domestic law of either or both of the treaty parties and the parties intended for the treaty term to have the meaning that the term has in their domestic laws.

What did the court in Tradehold have in mind with its reference to "international tax language"? One should note that the court referred to the phrase immediately after its statement that one cannot expect the words used in DTAs to perfectly match those used in domestic tax legislation. Arguably, the court may have been advocating the second possibility raised by Prokisch and felt it necessary to explain that a treaty term may have "a clear relation" not only to an identical term used in the domestic law, ${ }^{110}$ but also to a different, comparable term. Therefore, when determining the domestic meaning of a treaty term under the general renvoi clause (to which the court referred in its statement in the following paragraph), it is not

107 Du Plessis South African Perspective on Some Critical Issues 134-135. However, she includes at $\mathrm{n} 958$ the possibility that the court used a domestic meaning.

108 Du Plessis South African Perspective on Some Critical Issues 135. Also see Seiler 2013 BFIT 581.

109 Quoted in Du Toit Beneficial Ownership of Royalties 182. The expression "international tax language" is usually attributed to the UK case of Ostime (Inspector of Taxes) v Australian Mutual Provident Society [1960] AC 459. In that case, the court stated at 480 that the particular DTA employed "language ... [t]hat may be called international tax language, and that such categories [as some of the terms being interpreted] have no exact counterpart in the taxing code of the United Kingdom." (emphasis added)

110 As noted in $\mathrm{n} 114$ below, the definition of "disposal" did not yet form part of the ITA when the DTA was negotiated. However, as mentioned in the main text corresponding to $\mathrm{n} 83$, a definition of "alienation" or a comparable term is a common and thus anticipated feature in CGT legislation. 
surprising that the treaty and domestic laws may use different terms for the same concept.

The view preferred in this article is that the court's initial reference to the general renvoi clause is an indication that the court considered the domestic meaning of the treaty term as its starting point. As shown in the highlighted sentence in the last paragraph quoted from the judgment earlier, it then also considered whether the adoption of that meaning would be supported by the "context", which would arguably include the purpose of the DTA. ${ }^{111}$ It probably found that it would be supported. Otherwise, one would have expected it to consult possible aids to the determining of an alternative, autonomous meaning. These aids could have included foreign case law, writings of foreign scholars, or the Commentaries. ${ }^{112}$ As shown earlier, there is at least some guidance from these sources on the meaning of the treaty term "alienation" in the context of tax emigration.

The SCA concluded as follows, with the highlighted sentence possibly confirming the use of the domestic meaning of "disposal" under the general renvoi clause: ${ }^{113}$

[24] Article 13 is widely cast... It is reasonable to suppose that the parties to the DTA were aware of the provisions of the Eighth Schedule ${ }^{114}$ and must have intended article 13 to apply to capital gains of the kind provided in the Schedule ... There is, moreover, no reason in principle why the parties to the DTA would have intended that article 13 should apply only to taxes on actual capital gains resulting from actual alienations of property.

[25] Having regard to the factors mentioned, I am of the view that the term "alienation" as it is used in the DTA is not restricted to actual alienation. It is a neutral term having a broader meaning, comprehending both actual and deemed disposals of assets giving rise to taxable capital gains.

111 Van der Bruggen 2003 Euro Tax 147 and 153.

112 The place of the Commentaries under the VCLT has been the subject of debate. For a summary of some of the sources that deal with this debate, see Du Plessis South African Perspective on Some Critical Issues 100. There is also a question on whether the Commentaries can be taken into account as "context" under art 3(2) of the OECD MTC, in respect of which see the discussion by Rust "Article 3(2) OECD and UN MC" 212 m.nr. 123 and Avery Jones "Treaty Interpretation" para 5.1.1. However, there is no indication that the court in Tradehold refrained from referring to the Commentaries due to either of these debates.

113 Tradehold paras [24]-[25].

114 This is a somewhat surprising statement since the announcement of the introduction of CGT in the budget speech of 23 February 2000 post-dates the signature of the South Africa-Luxembourg DTA. The Eighth Schedule was inserted by way of legislation (s 38 of the Taxation Laws Amendment Act 5 of 2001) only after the DTA was already in force. Also see Seiler 2013 BFIT 580. 
3.3.3 The implications of the judgment for the issues considered in this article

Assuming that the SCA in Tradehold did indeed give the domestic meaning of "disposal" to the treaty term "alienation" under the general renvoi clause in the applicable DTA, what deductions can one make with regard to the issues discussed in part 2?

With regard to the issue highlighted in part 2.2, the SCA in Tradehold was prepared to give to a treaty term ("alienation" in this case) the meaning that a different expression ("disposal" in this case) bears in domestic legislation with reference to the general renvoi clause in the applicable DTA. It thus supports the view that the meaning of a different but comparable expression in the domestic law may in appropriate circumstances be taken into account under the general renvoi clause.

Furthermore, with regard to the question raised in part 2.3, that is whether deeming provisions in the domestic law may be taken into account under the general renvoi clause, the SCA's judgonment supports such a possibility. ${ }^{115}$

With regard to both these conclusions, the court emphasised the need to take into account the context, including the purpose of the DTA, when considering whether a domestic meaning should be used.

Lastly, with regard to the issue identified in part 2.4, that is whether a domestic meaning under article 3(2) should be used either "as a last resort", or as a matter of strong preference, the judgment does not make a clear impact. One can possibly say that the court accepted at the outset that a domestic meaning would apply and that it was looking for a reason why this should not be the case. This might thus indicate a preference for the domestic meaning. However, how "strong" the reasons for departing from this meaning should be is not apparent from the SCA's judgment.

\section{Conclusion}

General renvoi clauses in DTAs based on article 3(2) of the OECD MTC provide that an undefined term in a DTA shall have the meaning that it has in the domestic law of the contracting state applying the DTA unless the

\footnotetext{
115 However, note the following warning by Lewison LJ in his minority judgment in Fowler v The Commissioners for Her Majesty's Revenue and Customs [2018] EWCA Civ 2544 para [22]: "But I cannot extract from [Tradehold] the general proposition that a word used in a double tax treaty to describe a particular source of income or gain necessarily encompasses a domestic deeming provision, particularly where the word in question is defined in domestic tax law (which 'alienation' was not)."
} 
context otherwise requires. ${ }^{116}$ There are many issues pertaining to the application and interpretation of these clauses, only four of which are considered in this article.

The first issue arises in those scenarios where a domestic meaning was amended after the conclusion of the relevant DTA. The question is then whether an ambulatory or static approach should be preferred. Since the redrafting of article 3(2) in 1995, it clearly prescribes the ambulatory approach. Accordingly, the domestic meaning at the time of the application of the DTA is the relevant meaning. With regard to clauses in DTAs based on the pre-1995 version of article 3(2), the position is less clear. Arguably, this issue has not yet been directly addressed by South African courts, and also not by the AD in Baldwins. However, some comments in ITC 789 may indirectly support the adoption of the ambulatory approach.

The second issue arises in those scenarios where the domestic law uses an expression that differs from the term used in the DTA. The question to be considered is whether the domestic meaning of the different but comparable expression in the domestic law may be taken into account under the general renvoi clause. The decision of the SCA in Tradehold arguably supports this possibility. The court in ITC 1878 did not refer to the general renvoi clause, but it is noteworthy that it used the meaning of a different expression in the ITA when it interpreted an undefined term in a South African DTA.

Another issue concerns deeming provisions in domestic law. In particular, the issue is whether these deeming provisions pertaining to the domestic meaning of a term may under general renvoi clauses be taken into account when an undefined term in the applicable DTA is interpreted. Again, the decision in Tradehold supports this possibility.

The fourth issue considers whether a domestic meaning may under article 3(2) be applied only "as a last resort", or whether on the contrary it will apply unless there are "reasonably strong arguments" that the context requires otherwise. In Baldwins the AD showed a strong preference for the use of a domestic meaning under a general renvoi clause, indicating that it would depart from it only if the context "clearly" showed otherwise, or if there were some other reasons "of weight". The more recent judgment in Tradehold is not as clear in its expressed preference for the use of a domestic meaning.

The combined picture that emerges from these judgments over a 60-year period is that South African courts do not regard the use of domestic meanings under article 3(2) "as a last resort". They have instead been willing to use domestic meanings whilst noting the lack of weighty reasons

116 Or unless the competent authorities agree to a different meaning pursuant to the provisions of art 25. 
to the contrary. They were moreover prepared to do so even in those instances where the expression used in the domestic law differed from the term used in the DTA and in instances where the meaning in domestic law was based on a deeming provision. Possibly, they have also leaned towards a preference for the ambulatory approach as a matter of default in those cases where a general renvoi clause in a DTA does not expressly prescribe whether a static or ambulatory approach should be adopted.

\section{Bibliography}

\section{Literature}

Anonymous 2012 Taxpayer

Anonymous "Editorial Note to C: SARS v Tradehold Ltd" 2012 The Taxpayer $92-95$

Arnold 2008 BFIT

Arnold BJ "Time Thresholds in Tax Treaties" 2008 BFIT 218-231

Arnold 2010 BFIT

Arnold BJ "The Interpretation of Tax Treaties: Myth and Reality" 2010 BFIT $1-15$

Arnold 2012 BFIT

Arnold BJ "International - Tax Treaty Case Law News" 2012 BFIT 481-485

Avery Jones 2017 BTR

Avery Jones JF "HMRC v Fowler: More on Divers" 2017 BTR 385-398

Avery Jones 2019 BTR

Avery Jones JF "Fowler v HMRC: Divers yet Again" 2019 BTR 22-25

Avery Jones "Interaction between Tax Treaty Provisions and Domestic Law" Avery Jones JF "The Interaction between Tax Treaty Provisions and Domestic Law" in Maisto G (ed) Tax Treaties and Domestic Law (IBFD Amsterdam 2006) 123-160

Avery Jones "Treaty Interpretation"

Avery Jones JF "Treaty Interpretation" in Vann R (ed) Global Tax Treaty Commentaries (IBFD Amsterdam 2019)

Avery Jones and Hattingh 2016 BTR

Avery Jones and Hattingh "Fowler $v$ HMRC: Divers and the Dangers of Deeming" 2016 BTR 417-434 
Avery Jones et al 1984 BTR (I)

Avery Jones JF et al "The Interpretation of Tax Treaties with Particular Reference to Article 3(2) of the OECD Model - I" 1984 BTR 14-54

Avery Jones et al 1984 BTR (II)

Avery Jones JF et al "The Interpretation of Tax Treaties with Particular Reference to Article 3(2) of the OECD Model - II" 1984 BTR 90-108

Baker Double Taxation Conventions

Baker P Double Taxation Conventions (Sweet \& Maxwell London 2014)

Brilman 2015 BFIT

Brilman $L$ "The Effect of Taxation on Business Mobility in the European Union: The Case of the Netherlands" 2015 BFIT 442-449

Burt 2017 BTCLQ

Burt K "The OECD Commentaries: On what Legal Basis and to what Extent are they Relevant to Tax Treaty Interpretation" 2017 Business Tax \& Company Law Quarterly 5-28

Castro 2014 Intertax

Castro RT "When does 'the Context Otherwise Require' in Article 3 of the OECD Model Convention?" 2014 Intertax 709-719

Chand 2013 BFIT

Chand V "Exit Charges for Migrating Individuals and Companies: Comparative and Tax Treaty Analysis" 2013 BFIT 1-20

Classen 2013 SA Merc LJ

Classen LG "The Exit Tax Consequences of the Migration of Companies from South Africa: Commissioner for the South African Revenue Service $v$ Tradehold Ltd: Case Note" 2013 SA Merc LJ 387-403

De Broe International Tax Planning and Prevention of Abuse

De Broe L International Tax Planning and Prevention of Abuse: A Study under Domestic Tax Law, Tax Treaties and EC Law in Relation to Conduit and Base Companies (IBFD Amsterdam 2007)

De Broe "Tax Treatment of Transfer of Residence by Individuals"

De Broe L "The Tax Treatment of Transfer of Residence by Individuals General Report" in IFA Cahiers de Droit Fiscal International Vol 87b (IBFD Amsterdam 2002) 19-78 
De Pietro 2015 World Tax J

De Pietro C "Tax Treaty Override and the Need for Coordination between Legal Systems: Safeguarding the Effectiveness of International Law" 2015 World Tax J 73-97

Déry and Ward "Interpretation of Double Taxation Conventions"

Déry $\mathrm{J}$ and Ward DA "Interpretation of Double Taxation Conventions Canada" in IFA Cahiers De Droit Fiscal International Vol 78a (IBFD Amsterdam 1993) 259-293

Du Plessis 2012 SA Merc LJ

Du Plessis I "Some Thoughts on the Interpretation of Tax Treaties in South Africa" 2012 SA Merc LJ 31-52

Du Plessis 2016 TSAR

Du Plessis I "The Interpretation of Double Taxation Agreements: A Comparative Evaluation of Recent South African Case Law" 2016 TSAR 484-499

Du Plessis South African Perspective on Some Critical Issues

Du Plessis I A South African Perspective on Some Critical Issues Regarding the OECD Model Tax Convention on Income and on Capital, with Special Emphasis on its Application to Trusts (LLD-dissertation University of Stellenbosch 2014)

Du Toit Beneficial Ownership of Royalties

Du Toit CP Beneficial Ownership of Royalties in Bilateral Tax Treaties (IBFD Amsterdam 1999)

Du Toit and Hattingh "Beneficial Ownership"

$\mathrm{Du}$ Toit $\mathrm{C}$ and Hattingh $\mathrm{J}$ "Beneficial Ownership and Double Tax Conventions" in De Koker AP and Brincker E (eds) Silke on International Tax (LexisNexis Durban 2019) chapter 9

Edwardes-Ker Tax Treaty Interpretation

Edwardes-Ker M Tax Treaty Interpretation (PhD-dissertation University of London 1994)

Engelen Interpretation of Tax Treaties

Engelen FA Interpretation of Tax Treaties under International Law (IBFD Amsterdam 2004) 
Eskinazi "Interpretation of Double Taxation Conventions"

Eskinazi R "Interpretation of Double Taxation Conventions - South Africa" in IFA Cahiers De Droit Fiscal International Vol 78a (IBFD Amsterdam 1993) 545-558

Gutuza 2008 SALJ

Gutuza T "Taxing the Partner of a Foreign Partnership: Notes" 2008 SALJ 514-520

Gutuza 2014 SA Merc LJ

Gutuza T "Dual Residence and the Proviso: Where was Tradehold Resident?" 2014 SA Merc LJ 543-559

Gutuza 2016 SA Merc LJ

Gutuza T "Tax Treaties, the Income Tax Act and the Constitution - Trump or Reconcile" 2016 SA Merc LJ 480-507

Hattingh "South Africa"

Hattingh J "South Africa" in Brauner Y and Pistone P (eds) BRICS and the Emergence of International Tax Coordination (IBFD Amsterdam 2015) 231270

Kandev 2007 Can Tax J

Kandev MN "Tax Treaty Interpretation: Determining Domestic Meaning under Article 3(2) of the OECD Model" 2007 Can Tax J 31-71

Linderfalk and Hilling 2015 Nord Tax J

Linderfalk $U$ and Hilling $M$ "The Use of OECD Commentaries as Interpretative Aids: The Static/Ambulatory-Approaches Debate Considered from the Perspective of International Law" 2015 Nord Tax J 34-59

Mazansky 2012 BFIT

Mazansky E "South Africa's Exit Charge Overridden by the LuxembourgSouth Africa Income and Capital Tax Treaty (1998)" 2012 BFIT 374-376

Mooij 2019 BTR

Mooij H "Fowler v HMRC: An Outside View" 2019 BTR 25-30

Olivier and Honiball International Tax

Olivier L and Honiball M International Tax: A South African Perspective $5^{\text {th }}$ ed (Siberlnk Cape Town 2011) 
Pijl 1997 BFIT

Pijl $H$ "The Theory of the Interpretation of Tax Treaties, with Reference to Dutch Practice" 1997 BFIT 539-546

Pötgens Income from International Private Employment Pötgens F Income from International Private Employment: An Analysis of Article 15 of the OECD Model (IBFD Amsterdam 2007)

Rust "Article 3(2) OECD and UN MC"

Rust A "Article 3(2) OECD and UN MC" in Reimer E and Rust A (eds) Klaus Vogel on Double Taxation Conventions Volume I (Kluwer Law International Alphen aan de Rijn 2015) 206-215

Seiler 2013 BFIT

Seiler M "Exit Taxation Arising from a Deemed Disposal of Shares" 2013 BFIT 580-583

Simontacchi Taxation of Capital Gains

Simontacchi S Taxation of Capital Gains under the OECD Model Convention: With Special Regard to Immovable Property (Kluwer International Law Alphen aan den Rijn 2007)

Van der Bruggen 2003 Euro Tax

Van der Bruggen E "Unless the Vienna Convention otherwise Requires: Notes on the Relationship between Article 3(2) of the OECD Model Tax Convention and Articles 31 and 32 of the Vienna Convention on the Law of Treaties" 2003 Euro Tax 142-156

Wattel and Marres 2003a Euro Tax

Wattel PJ and Marres $O$ "Characterization of Fictitious Income under OECD-Patterned Tax Treaties" 2003 Euro Tax 66-79

Wattel and Marres 2003b Euro Tax

Wattel PJ and Marres O "The Legal Status of the OECD Commentary and Static or Ambulatory Interpretation of Tax Treaties" 2003 Euro Tax 222-235

\section{Case law}

\section{Canada}

$R v$ Melford Development Inc 82 DTC 6281 
South Africa

Baldwins (South Africa) Ltd v Commissioner for Inland Revenue 196124 SATC 270

Canca v Mount Frere Municipality 19842 SA 830 (Tk)

Clutchco (Pty) Ltd v Davis 20053 SA 486 (SCA)

Commissioner for the South African Revenue Service v Tradehold Ltd 2012 3 All SA 15 (SCA)

Cronje v Paul Els Investments (Pty) Ltd 19822 SA 179 (T)

Govindasamy v Indian Immigration Trust Board Natal 1918 AD 633

Grobler v Trustee Estate De Beer 1915 AD 265

ITC 789195419 SATC 434

ITC 1848201073 SATC 170

ITC 1878201577 SATC 349

Minister of Mineral Resources $v$ Sishen Iron Ore Co (Pty) Ltd 20142 SA 603 (CC)

SATAWU v Garvas 20131 SA 83 (CC)

\section{The Netherlands}

Decision by the Hoge Raad (20 February 2009) 42701 BNB 2009/260

Decision by the Hoge Raad (20 February 2009) 43760 BNB 2009/261

Decision by the Hoge Raad (20 February 2009) 07/12314 BNB 2009/262

\section{United Kingdom}

Ostime (Inspector of Taxes) v Australian Mutual Provident Society [1960] AC 459

Fowler $v$ The Commissioners for Her Majesty's Revenue and Customs [2018] EWCA Civ 2544 


\section{Legislation}

\section{South Africa}

Alienation of Land Act 68 of 1981

Constitution of the Republic of South Africa, 1996

Housing Development Schemes for Retired Persons Act 65 of 1988

Income Tax Act 31 of 1941

Income Tax Act 58 of 1962

Property Time-Sharing Control Act 75 of 1983

Taxation Laws Amendment Act 5 of 2001

\section{The Netherlands}

Wet op de inkomstenbelasting 2001

International intruments

OECD Model Tax Convention on Income and Capital (latest revision 2017) Vienna Convention on the Law of Treaties (1969)

\section{Internet sources}

OECD 1991 http://dx.doi.org/10.1787/9789264239081-102-en Organisation for Economic Cooperation and Development 1991 The 183 Day Rule: Some Problems of Application and Interpretation http://dx.doi.org/10.1787/9789264239081-102-en accessed 15 December 2015 


\section{List of Abbreviations}

$\begin{array}{ll}\text { AD } & \text { Appellate Division, before being restructured } \\ \text { BFIT } & \text { as the Supreme Court of Appeal } \\ \text { Bulletin for International Taxation } & \text { Business Tax \& Company Law Quarterly } \\ \text { BTCLQ } & \text { British Tax Review } \\ \text { BTR } & \text { Canadian Tax Journal } \\ \text { Can Tax J } & \text { Capital gains tax } \\ \text { CGT } & \text { Double taxation agreement } \\ \text { DTA } & \text { European Taxation } \\ \text { Euro Tax } & \text { International Bureau } \\ \text { IBFD } & \text { Documentation for } \\ & \text { International Fiscal Association } \\ \text { IFA } & \text { Income Tax Act } \\ \text { ITA } & \text { Nordic Tax Journal } \\ \text { Nord Tax J } & \text { Non-resident shareholders' tax } \\ \text { NRST } & \text { Organisation for Economic Cooperation and } \\ \text { OECD } & \text { Development } \\ \text { OECD MTC } & \text { OECD Model Tax Convention on Income and } \\ & \text { on Capital } \\ \text { SA Merc LJ } & \text { South African Mercantile Law Journal } \\ \text { SCA } & \text { Supreme Court of Appeal } \\ \text { SALJ } & \text { South African Law Journal } \\ \text { TSAR } & \text { Tydskrif vir die Suid-Afrikaanse Reg } \\ \text { UK } & \text { United Kingdom } \\ \text { US } & \text { United States } \\ \text { VCLT } & \text { Vienna Convention on the Law of Treaties } \\ \text { World Tax J } & \text { World Tax Journal } \\ & \end{array}$

